he deals has been accumulating for many years in the collections of the Geological Survey of India, and some of the specimens are preserved in the British Museum. As Prof. Sahni remarks, it is unfortunate that the localities and horizons of so many of the specimens are not known with certainty. In spite of this serious disadvantage, Prof. Sahni adds very considerably to our knowledge of the Coniferales.

Most of the petrifactions are of secondary wood and belong to either the Jurassic or Cretaceous age. They include the following form genera: Mesembrioxylon, Cupressinoxylon, and Dadoxylon (Araucarioxylon). It is curious that there is no mention of Dadoxylon indicum or Dadoxylon bengalense Holden, two palæozoic fossil woods which are certainly gymnospermous, while the latter is as likely to be coniferous, in view of its structure, as any of the Mesozoic species of Dadoxylon described by Prof. Sahni. These two Indian fossil woods are particularly interesting, since they resemble, in certain important characters, species described from the Karroo formation in South Africa. Prof. Sahni cites this work by Holden in part 1, but does not mention either of these two species.

A new genus of cone, Indostrobus, is described. It bears bract and ovuliferous scales as in the living pine, but differs in the ovuliferous scale being forked at its distal end. The seeds are placed on the ovuliferous scale at some distance from the cone axis. Prof. Sahni recognises features reminiscent of the podocarps in the structure of this cone; but at the same time is clear that it is most closely related to the Pinaceæ. He also produces clear evidence of the existence of araucarian conifers in the Jurassic of the Gondwana system. The podocarps, if one may judge not only from the various types of fruits and foliage but also from the numerous examples of secondary wood, were abundant and had a wide geographical distribution in India in the Jurassic and Cretaceous.

The contrast between the present and past distribution of conifers in India is stressed by Prof. Sahni. There is only one native conifer in peninsular India at the present day. There is no native living conifer in Ceylon. The living conifers are restricted, in greater India, to the Himalayas with their con- nected ranges and to Assam and Burma. In the Tertiary Period there is apparently an almost com. plete absence of conifers in the India floras so far investigated, and the Indian Tertiary floras would appear to have been almost exclusively angiospermous. There is only one record of Indian Tertiary coniferous wood and that is from Southern India. In the Cretaceous Period the traces of conifers are fairly numerous, but the group appears to have enjoyed its maximum development in the Jurassic. It is a remarkable fact that no fossil conifers are recorded from extra-peninsular India.

On the strength of these facts, Prof. Sahni concludes that the conifers were confined in Mesozoic times to peninsular India. Later they gradually approached extinction, and when the Himalayas were brought into existence in the Tertiary Period the conditions for coniferous growth were reintroduced and an invasion of the modern coniferous flora took place from the landward borders.

From a consideration of their respective floras, Prof. Sahni considers that the Parsora Stage of Dr. Cotter's 1917 classification of the Indian Gondwana System is of Triassic age, and that the Maleri Stage must be referred to the Upper Gondwanas and not, as has been done previously, to the Lower; for the flora suggests an age at least as late as the Rhætic. $\mathrm{He}$ considers that while it is clear that Ceylon and the Madras region formed part of the same palæobotanical province in Upper Gondwana times, it is possible that the flora of the Mesozoic plant-beds of the Southern Shan States had a closer connexion with the contemporaneous floras in China than with the Indian Upper Gondwana floras.

Valuable synoptic charts and distribution maps are given. One of the many outstanding good qualities of these memoirs is the excellence of the illustrations, and by means of these the evidence is put before the reader in a manner which leaves little to be desired. All palæobotanists and those geologists who are interested in the stratigraphy of the Indian Gondwana System will look forward to the extension of Prof. Sahni's researches to the other groups of Indian fossil plants.

\title{
Physics in Relation to the Internal Combustion Engine.*
}

THE development of all internal combustion engines using gas or oil as a fuel and for all duties, whether stationary on land or for transport, road, marine, or in the air, owes more to the guidance of physics than any other prime mover.

In the first period, when the engine was nearly always a gas engine, the investigation of the processes which governed its action and the limitation of its cycle of working were carpied out by physicists like Sir Dugald Clerk, Prof. Hopkinson, and others. The results assisted and accelerated development, making possible the extended use of the engine for all industrial purposes that followed.

Perhaps the outstanding feature during this time was the growth of the engine in size, until ultimately engines using the waste gases from blast furnaces were built, or are building, for powers so large as 10,000 h.p. per engine. These large-size engines are found usually abroad, operating in the most efficient iron and steel works. As regards the smaller sizes in Great Britain, they would have been used more widely if the gas industry had foreseen the possibilities of a country. wide gas supply with interconnecting trunk mains, as has been done since by the electrical industry.

The War period followed, and led to an intensive

* From a lecture delivered by Alan E. L. Chorlton before the Institute of Physics on May 19. and rapid development in the engine for transport, in particular in the air, where special materials and increased accuracy of workmanship were called for. The extraordinary progress made was largely due to the number of highly trained physicists and engineers who concentrated upon every problem and solved it as it arose.

Since the War, development has been in the use of oil, and the wide adoption of the engine for marine propulsion has been due to the high economy of the Diesel motor. The high economic possibilities of this engine were thoroughly discussed in a paper by Diesel before the engine was actually built, and though it took many years to bring this into practice the results have justified all that he had proposed. At the present time, development is being concentrated upon the high-speed oil motor using relatively cheap fuel, with the added advantage of reducing the risk of fire, for road transport and for the air, and very good progress is being made.

The first 'safety first' engines to fly regularly were those supplied to the airship R101. Since then one has flown in the United States and one in Germany, and these will shortly be followed by another type in Great Britain.

On the road, extraordinary progress has taken place in the application of the small engine to motor lorries,

No. 3212 , VoL. 127] 
etc., the economy with cheaper fuel and using less of it has been so marked. This class of engine has called for the most intensive investigation and research that has ever been carried out in the internal combustion engine world. Much valuable laboratory work has been carried out in the United States by the National Advisory Committee for Aeronautics in connexion with their air work, and elsewhere.

This reveals the intensity of effort which will before long ensure that not only will the oil engine become predominant for road work of heavier nature, but also for the air, where its great safety from the fire risk, coupled with its economy, makes it so highly suitable. The use of coal dust in the engine progresses very slowly for a country like England, the industrial supremacy of which is founded on coal. This is to be regretted, and we should conduct special work with this object.

In all the development of the engine, the steady improvement of the material has been the measure of the progress made. To-day we have new steels practically unwearable--allowing high speeds and long life, and also of such strength that motors like the Schneider Cup engine weigh less than $1 \mathrm{lb}$. per h.p.and a degree of excellence of workmanship not excelled, if equalled, in all the world.

\section{University and Educational Intelligence.}

Birmingham.-At the annual degree congregation on July 4, the honorary degree of M.Sc. is to be conferred on the following: R. A. Chattock, formerly chief electrical engineer to the City of Birmingham; W. Wickham King, known for his work on the Permian breccia; J. H. Reynolds, who has made a special study of the nebulæ; and J.J. Shaw, known for his seismological work.

Prof. J. C. Brash is resigning his posts as professor of anatomy and dean of the Faculty of Medicine on being appointed to the chair of anatomy in the University of Edinburgh.

Cambridge.-A meeting of the electors to the Sadleirian professorship of pure mathematics will be held on June 12. The stipend of the professor is $£ 1200$ a year or, if he holds a fellowship with dividend, $£ 1000$ a year. Candidates are requested to communieate with the Vice-Chancellor on or before June 2 .

A University lectureship in the faculty of mathematics is vacant. An appointment to it will be made in the current term, to take effect from Oct. 1 . Candidates are requested to send their names, with any evidence of qualifications which they may desire to submit, to Mr. W. J. Harrison, Secretary of the Faculty Board of Mathematics, Clare College, Cambridge, on or before May 30 .

The General Board recommends that an additional University demonstratorship be established in the Department of Zoology.

Prof. G. Elliot Smith, professor of anatomy in University College, London, has been elected an honorary fellow of St. John's College.

London.--At a meeting of the Court of the University held on May 13, the Principal, Dr. Edwin Deller, read his annual report of the work of the University for the year $1930-31$. The statistics for that year have brought out some striking facts concerning the number of students. For example, the number of matriculations has almost quadrupled since just before the War. A great increase has taken place in all branches of study. For the year 1913, the numbers of matriculations, first degrees, and higher degrees were 6638,1636 , and 171 respectively. The corresponding numbers for 1929 were $23,832,3436$, and 510 , and for
$1930,25,544,3543$, and 548 . The total number of degrees, diplomas, and certificates awarded for those three years were $11,937,36,633$, and 39,323 . During the last decade, the inspection and examination of secondary schools have received much attention, and the growth of the school examinations has been specially noteworthy.

The Goldsmiths' Company has offered the University a sum not exceeding $£ 50,000$ towards the cost of erecting and equipping the library building on the Bloomsbury site. The University library, at present housed in the Imperial Institute, South Kensington, contains a total of some 260,000 volumes and pamphlets, and includes, with other special collections, the Goldsmiths' Library of Economic Literature.

Applications for grants from the Research Fund of the Chemical Society must reach the Assistant Secretary of the Society, Burlington House, W.1, by June 1, and be made upon special forms obtainable upon application.

Applcations are invited by the London County Council for two Robert Blair fellowships in applied science and technology, each of the value of $£ 450$ and for one year. The fellowships will be tenable in the Dominions, the U.S.A. or other foreign countries, and are open only to British subjects of not less than twenty-one years of age. Particulars and application forms can be had from the Education Officer (T.3), The County Hall, S.E.1. The latest date for the return of forms of application is June 18.

A NUMBER of post-graduate scholarships in agriculture and agricultural science and in veterinary science respectively will shortly be awarded by the Colonial Office. The scholarships, which will each be of the annual value of $£ 250$, plus $£ 12$ for books, have been instituted with the view of ensuring a supply of adequately trained men for future service in the Colonial Agricultural and Veterinary Services. $R e-$ quests for particulars of the scholarships and for the necessary forms of application should be addressed to the Director of Recruitment (Colonial Sorvice), Colonial Office, 2 Richmond Terrace, Whitehall, S.W.1. The latest date for the return of completed forms is June 15.

THE twenty-second annual Conference of the Association of Teachers in Technical Institutions will be held at Manchester on May 22-26, under the presidency of Mr. H. Ade Clark. The Conference will be held at the College of Technology. In connexion with the Conference an exhibition of machines, scientific apparatus, and books will be opened on May 25. Among the resolutions for public sessions is the motion that a representative of technical education should be appointed to the Consultative Committee of the Board of Education. The teaching of biology, too, will receive consideration. A considerable amount of biology is taught in many technical schools and colleges; but this is chiefly of a purely technical character for the benefit of pharmaceutical chemists. The resolution to be placed before the Conference, however, will be of a wider nature. It is considered that a knowledge of biology is an essential part of a sound general education, and that more experts in the subject are required for the advancement of agriculture and industry. The Conference is to ask for the teaching of elementary biology in all State-aided schools and an increase in the facilities for higher education in biological subjects. The latter is scarcely necessary. The facilities are there; but the former really needs attention. A better groundwork in the younger pupils is certainly desirable. Much has already been suggested concerning it; but little, so far, has been done.

No. 3212, VoL. 127] 